\title{
Medical Therapy for Pediatric Vascular Anomalies
}

\author{
Judith F. Margolin, MD ${ }^{1}$ Heather Mills Soni, CPNP ${ }^{1}$ Sheena Pimpalwar, MD² \\ ${ }^{1}$ Baylor College of Medicine, Texas Children's Cancer and Hematology \\ Service, Houston, Texas \\ 2 Division of Interventional Radiology, Department of Radiology, TCH, \\ Baylor College of Medicine, Houston, Texas

\begin{abstract}
Address for correspondence Judith F. Margolin, MD, Department of Pediatrics, Baylor College of Medicine, Texas Children's Cancer and Hematology Service, Suite 1510, Clinical Care Center, 6701 Fannin
\end{abstract} \\ Street, Houston, Texas 77030 (e-mail: jfmargol@txch.org).
}

Semin Plast Surg 2014;28:79-86.

\begin{abstract}
Keywords

- vascular anomalies

- chemotherapy

- sirolimus

- kaposiform hemangioendothelioma

- tufted angioma

- blue rubber bleb nevus syndrome

Vascular anomalies (VAs) comprise a large variety of individual diagnoses that in different phases of treatment require a diverse number of medical specialists to provide optimal care. Medical therapies include agents usually associated with cancer chemotherapy, such as vincristine, as well more immunomodulatory types of drugs, such as glucocorticoids and sirolimus. These immunomodulating drugs are being successfully applied in cases that are typically categorized as vascular tumors, including kaposiform hemangioendothelioma (KHE) and tufted angioma (TA), as well as some of the more invasive types of vascular malformations (i.e., microcystic lymphatic malformations and blue rubber bleb nevus syndrome (BRBNS). These therapies need to be combined with good supportive care, which often involves anticoagulation, antimicrobial prophylaxis, and comprehensive pain and symptom-relief strategies, as well as appropriate drug monitoring and management of side effects of medical treatment. The optimal care of these patients frequently involves close collaboration between surgeons, interventional and conventional radiologists, medical subspecialists, and nurses.
\end{abstract}

Vascular anomalies (VAs) comprise a large variety of individual diagnoses that in different phases of treatment require a diverse number of medical specialists to provide optimal care. Many of these patients require multi- or interdisciplinary care, which can be provided either by enrollment in or consultation with VA centers. ${ }^{1,2}$ Vascular anomalies themselves are now classified using the International Society for the Study of Vascular Anomalies (ISSVA) system, which divides VAs between vascular tumors and vascular malformations. ${ }^{3,4}$ Consensus regarding diagnostic terminology and accurate classification of disease is critical to the appropriate selection of therapy and coordination between subspecialists. Without such agreement, a large number of these patients often fail to receive appropriate diagnosis or treatment. Overlapping clinical and imaging findings combined with the persistence of older terminology may cause difficulties applying the ISSVA system, but several recent publications should lessen this confusion. ${ }^{4,5}$ The reader must be careful when reading the literature on VAs because as recently as 2009 one author was able to identify the incorrect usage of the term "hemangioma" in $>70 \%$ of the literature published that year. ${ }^{6}$ Medical therapies for these diseases can be roughly divided between agents and procedures targeted at controlling cellular proliferation/abnormal growth, and others that are aimed at avoiding the hemostatic and general medical consequences (bleeding, thrombosis, infection, anemia, and pain) from these diseases and from potentially toxic therapies.

The role of a pediatric hematologist/oncologist in the VA interdisciplinary team is threefold and includes

1. Participation in the rigorous diagnostic process, which includes tissue biopsy, to be sure that each patient's diagnosis is properly defined. The need for tissue biopsy cannot be overemphasized. Unless it is clearly medically contraindicated, a biopsy should be performed prior to initiation of cytotoxic and/or immunosuppressive therapy.
Issue Theme Vascular Anomalies; Guest Editor, Edward I. Lee, MD
Copyright $\odot 2014$ by Thieme Medical Publishers, Inc., 333 Seventh Avenue, New York, NY 10001, USA. Tel: +1(212) 584-4662. 
2. Selection, monitoring, and supervision of the delivery of chemotherapy and the coordination of this care with ongoing needs for further surgical and interventional radiology (IR) procedures that may be required beyond the initial diagnosis.

3. Provision of appropriate anticoagulation and general medical care. A general pediatrician can provide medical care for VA patients; however, in many cases patients with rare VA diagnoses often present with a severe degree of illness, and are initially managed in the outpatient and inpatient settings by pediatric hematologist-oncologists in collaboration with other medical subspecialists.

This review will concentrate on the medical therapies (outlined in -Table 1) that are specifically used on the nonhemangioma vascular tumors outlined in the ISSVA classification, including kaposiform hemangioendothelioma (KHE) and tufted angioma (TA), as well as vascular malformations that have proven refractory to surgical and IR techniques. Specifically, some lymphatic malformations (LMs) and blue rubber bleb nevus syndrome (BRBNS) can be treated quite successfully with sirolimus. The diagnosis and care for the multiple types of hemangiomas is covered by other articles in this journal as well other recent reviews. ${ }^{7}$ The complexities of anticoagulant care for children are beyond the scope of this article, but are obviously relevant for the care of many of these children, and have been recently reviewed. ${ }^{8,9}$ The reader is cautioned to seek consultation with colleagues familiar with these diagnoses and treatment of these disorders before initiating therapy. Free consultative services (performed by e-mail/mail or phone) for referring physicians are available at several VA centers. Nevertheless, it may be advisable to formally refer a patient to an institution with an active VA service. When a patient is referred to such a center, an individualized treatment plan can be designed (often to be implemented by the referring physician alone or in collaboration with the VA center), and where possible the patient can be enrolled on institutional and occasionally national treatment trials and databases that are part of the process of improving the medical care and knowledge in this disparate field.

- Table 1 is a list of the current, most commonly used medications for the treatment of vascular tumors, and some of them have been applied to selective vascular malformations. Many of these agents (i.e., prednisone and vincristine) have been licensed for use in pediatric oncology for decades, and have well-known acute and chronic side effects. Other agents (i.e., propranolol and sirolimus) have been licensed for other medical indications for many years, but their use in VA therapy is relatively new. With the exception of infantile hemangiomas, all of the other vascular tumors are quite rare.

\section{Vascular Tumors}

\section{Kaposiform Hemangioendothelioma and Tufted Angioma}

Kaposiform hemangioendothelioma (KHE) is the most common of these entities, though it is so rare that the incidence has only recently been estimated as $\sim 0.071$ cases per 100,000 children. ${ }^{10,11}$ Patients usually present in early infancy, but both prenatal and adult-onset cases of KHE have been described. Due to the age of the patients at presentation and the obvious vascular nature of the lesions, KHE can initially be confused with infantile hemangioma, but the histology and natural history of these two diseases are quite distinct. Infantile hemangiomas are usually confined to the skin, although liver involvement is frequently described and can be multifocal. Kaposiform hemangioendothelioma is an infiltrative tumor, with distinct histology, which often crosses tissue planes invading fascia, muscle, and occasionally bone. Although rare cases of metastatic KHE have been described, it is generally found as a single, infiltrative tumor that most commonly involves an extremity although lesions of the torso (including intrathoracic cavity, Case 1), and the retroperitoneum are also seen. The histologic features include infiltrating nodules as well as sheets of spindle-shaped cells, slit-like vascular channels, and focal positivity for lymphatic endothelial markers (i.e., D2-40, Prox1 and Lyve-1 positive). Severe KHE presents with Kasabach-Merritt phenomenon or syndrome (KMP or KMS) and it is the KMP feature coupled with the large size of many of these lesions (Case 1 ) in very young children that are the major causes of the published $12 \%$ to $30 \%$ mortality from this disease. The mortality figures come from older literature and are probably much lower when KMP-related hemorrhage and the disease itself is addressed with more current therapies. Occasionally, KHE is diagnosed in older children and adults without the associated KMP, and can be cured surgically if the lesion can be fully resected with negative margins. ${ }^{11,12}$ Generally, it is present as a single infiltrative lesion, but occasional cases of metastasis versus possible second primary lesions have been described. The presence of associated and distant lymphatic malformations (usually denoted as lymphangiomatosis) lesions have also been described in rare cases, and the etiology/significance of these is unknown. ${ }^{12}$

For many years, KHE was managed with combination chemotherapy-most prominently intravenous (IV) vincristine and moderate- to high-dose glucocorticoids (usually 2-4 $\mathrm{mg} / \mathrm{kg} / \mathrm{d}$ of prednisone). Although this is a successful therapy for as many as $70 \%$ of patients, the remaining $30 \%$ would not respond at all, respond poorly, and/or suffer recurrences when the therapy was stopped. These medications can have significant short-term side effects, especially when they are used for the 6 to 18 months that is usually required for KHE therapy. Vincristine is a sclerosing IV agent, which can cause severe soft tissue damage if inadvertently infiltrated into tissues, and can have significant side effects ranging from minor to major neuropathy, seizures, and constipation/obstipation. Because the average KHE patient is an infant or very young child, a central line is advisable when using this type of chemotherapy. Although a biopsy is important for definitive diagnosis, resection should only be attempted if the lesion can be completely removed without causing deformity. Vincristine and other standard chemotherapy agents should be mixed in pharmacies with significant practice mixing such agents, and delivered in settings (i.e., a hematology-oncology 
Table 1 Medications that have been or are currently being used to treat vascular anomalies (both tumors and malformations)

\begin{tabular}{|c|c|c|c|c|}
\hline Agent & Dosage(s) & $\begin{array}{l}\text { Diagnoses and com- } \\
\text { ments on use }\end{array}$ & $\begin{array}{l}\text { Side Effects and } \\
\text { Precautions }\end{array}$ & References \\
\hline $\begin{array}{l}\text { Sirolimus (Rapamycin)- } \\
\text { use in VAs still considered } \\
\text { investigational-if not } \\
\text { used as part of a clinical } \\
\text { trial, consultation with a } \\
\text { physician familiar with its } \\
\text { use in VAs should be } \\
\text { sought. }\end{array}$ & $\begin{array}{l}0.8 \mathrm{mg} / \mathrm{m}^{2} / \text { dose every } \\
12 \mathrm{~h} \\
\text { Or } 1 \mathrm{mg} / \mathrm{kg} / \mathrm{d} \text { divided } \\
\text { twice daily } \\
\text { Target trough: } 10-15 \\
\text { ng/mL or lower if } \\
\text { toxicity intervenes }\end{array}$ & $\begin{array}{l}\text { KHE,TA, LM, PTEN muta- } \\
\text { tion patients (BRRS and } \\
\text { other), blue rubber bleb } \\
\text { syndrome, GSD, other } \\
\text { Usually used as a single } \\
\text { agent }\end{array}$ & $\begin{array}{l}\text { Trough levels must be } \\
\text { monitored; target levels } \\
\text { vary in the literature } \\
\text { hyperlipidemia; immuno- } \\
\text { suppressant (consider- } \\
\text { ation for prophylactic } \\
\text { antibiotics/antifungal } \\
\text { agents) }\end{array}$ & $1,13-15,21,26,27$ \\
\hline $\begin{array}{l}\text { Corticosteroids: } \\
\text { Prednisolone PO } \\
\text { Prednisone PO } \\
\text { Methylprednisolone } \\
\text { (HD) IV }\end{array}$ & $\begin{array}{l}1-2 \mathrm{mg} / \mathrm{kg} / \mathrm{d} \text { or } \\
\text { divided twice daily }\end{array}$ & $\begin{array}{l}\text { Hemangiomas, KHE, KLA, } \\
\text { Usually used in conjunc- } \\
\text { tion with other agents }\end{array}$ & $\begin{array}{l}\text { Immunosuppressive, hy- } \\
\text { pertension, hyperglyce- } \\
\text { mia, osteoporosis, } \\
\text { cataracts (long-term } \\
\text { use), adrenal } \\
\text { insufficiency }\end{array}$ & $1,2,10,11,14,21$ \\
\hline $\begin{array}{l}\text { Vincristine, chemothera- } \\
\text { peutic, should be admin- } \\
\text { istered by a chemo } \\
\text { certified/qualified nurse- } \\
\text { preferably written by a } \\
\text { hematologist/oncologist } \\
\text { in a clinic where VCR is } \\
\text { routinely given }\end{array}$ & $\begin{array}{l}1.5 \mathrm{mg} / \mathrm{m}^{2} / \text { dose IV } \\
\text { once weekly-once } \\
\text { monthly }\end{array}$ & $\begin{array}{l}\text { KHE, TA, hemangiomas } \\
\text { (not first line for this in- } \\
\text { dication), KLA, GLA } \\
\text { Usually used in conjunc- } \\
\text { tion with other agents } \\
\text { (frequently with steroids) }\end{array}$ & $\begin{array}{l}\text { Scleroscent (preferable to } \\
\text { give in a central line), } \\
\text { constipation, obstipation, } \\
\text { neurotoxicity including } \\
\text { numbness, tingling, im- } \\
\text { pairment of propriocep- } \\
\text { tion, seizures }\end{array}$ & $1,2,9,10,13,21$ \\
\hline $\begin{array}{l}\text { Interferon-2 } \alpha \text { or } \\
\text { Interferon-2 } \beta\end{array}$ & $\begin{array}{l}\text { 1-3 million units } / \mathrm{m}^{2} / \mathrm{d} \\
\text { - start at lower dose } \\
\text { and gradually escalate } \\
\text { Pegylated forms with } \\
\text { different dosing rec- } \\
\text { ommendations avail- } \\
\text { able-but less tested in } \\
\text { VAs }\end{array}$ & $\begin{array}{l}\text { Second- or third-line } \\
\text { treatment for KHE. Used } \\
\text { sporadically in other VAs. } \\
\text { First-line therapy for GSD } \\
\text { according to at least one } \\
\text { group }\end{array}$ & $\begin{array}{l}\text { Flu-like symptoms, ane- } \\
\text { mia, depression, throm- } \\
\text { bocytopenia, hypothy- } \\
\text { roidism, do not use in } \\
\text { patients }<1 \text { year old- } \\
\text { can cause irreversible } \\
\text { spastic diplegia }\end{array}$ & 29 \\
\hline $\begin{array}{l}\text { Thalidomide (and } \\
\text { lenalidomide) }\end{array}$ & $\begin{array}{l}\text { Experimental use only } \\
\text {-not discussed in this } \\
\text { article. Consult with a } \\
\text { VA center experienced } \\
\text { in the use of these } \\
\text { agents before consid- } \\
\text { ering using. }\end{array}$ & $\begin{array}{l}\text { Experimental use for AVM } \\
\text { Thalidomide starting } \\
\text { dose } \\
50 \mathrm{mg} \text { child, } 100 \mathrm{mg} \\
\text { adult QHS-higher doses } \\
\text { are published in the liter- } \\
\text { ature, consider starting } \\
\text { lower in small children. } \\
\text { (consult with a physician } \\
\text { familiar with these } \\
\text { medications) }\end{array}$ & $\begin{array}{l}\text { Use of these agents is } \\
\text { restricted (requires man- } \\
\text { ufacturer's approval to } \\
\text { write) dosages are devel- } \\
\text { oped from use for other } \\
\text { indications. SEs: Nausea, } \\
\text { fatigue, cytopenias, hypo- } \\
\text { magnesemia, can cause } \\
\text { severe birth defects. Pa- } \\
\text { tients with child-bearing } \\
\text { potential need to be } \\
\text { counseled and frequently } \\
\text { tested. }\end{array}$ & $32-34$ \\
\hline Propranolol & $\begin{array}{l}1-3 \mathrm{mg} / \mathrm{kg} / \mathrm{d} \text { divided } \\
\text { twice daily or } 3 \text { times a } \\
\text { day }\end{array}$ & Hemangiomas, KHE, TA & $\begin{array}{l}\text { Bradycardia, hypoten- } \\
\text { sion, hypoglycemia, diar- } \\
\text { rhea, wheezing, poor } \\
\text { feeding in infants. May } \\
\text { need to titrate to dose; } \\
\text { taper to stop }\end{array}$ & 7 \\
\hline Cyclophosphamide & $\begin{array}{l}50-1000 \mathrm{mg} / \mathrm{m}^{2} / \text { dose } \\
\text { - single vs. multiday } \\
\text { schedules, give with } \\
\text { hydration. Schedules } \\
\text { taken from the oncol- } \\
\text { ogy literature and vary } \\
\text { widely. }\end{array}$ & $\begin{array}{l}\text { KHE, refractory heman- } \\
\text { giomas, other fast-grow- } \\
\text { ing proliferative lesions } \\
\text { that have failed other } \\
\text { therapies chemothera- } \\
\text { peutic, should be mixed } \\
\text { and administered by a } \\
\text { chemo certified/qualified } \\
\text { personnel }\end{array}$ & $\begin{array}{l}\text { Acute nausea, vomiting, } \\
\text { occasional diarrhea. } \\
\text { Dose-dependent neutro- } \\
\text { penia, thrombocytope- } \\
\text { nia, anemia, } \\
\text { hepatotoxicity, hemor- } \\
\text { rhagic cystitis (at higher } \\
\text { doses) }\end{array}$ & $\begin{array}{l}\text { Used in older literature } \\
\text {-shouldn't be consid- } \\
\text { ered for use in modern } \\
\text { VA therapy unless/un- } \\
\text { til other agents have } \\
\text { failed }\end{array}$ \\
\hline
\end{tabular}

Abbreviations: AVM, arteriovenous malformation; BRRS, Bannayan-Riley-Ruvalcaba Syndrome; GSD, Gorham-Stout Disease; GLA, generalized lymphatic anomaly; IV, intravenous; KHE, kaposiform hemangioendothelioma; KLA, Kaposiform Lyphangiomatosis; LM, lymphatic malformations; PO, by mouth; PTEN, phosphatase and tensin homolog; QHS, nightly; TA, tufted angioma; VA, vascular anomalies; VCR, Vincristine. 
clinic or infusion center familiar with this type of care) by personnel who have the appropriate experience and certification for handling these agents.

Although the older literature focuses in the use of vincristine and steroids for this lesion, there is growing evidence that many KHE lesions will respond to sirolimus. ${ }^{13,14}$ Sirolimus (also known as rapamycin) is a potent inhibitor of a serine/ threonine kinase known as mammalian target of rapamycin or mTOR. mTOR is a master switch that works through PI3 kinase and a protein known as AKT to control many cellular processes involved in growth, but seems to be particularly important for vascular growth. ${ }^{1,14,15}$ Various doses for sirolimus use have been proposed but $0.1 \mathrm{mg} / \mathrm{kg} / \mathrm{d}$ divided twice daily for infants and 0.8 to $1 \mathrm{mg} / \mathrm{m}^{2} / \mathrm{d}$ divided twice daily for older children have been successfully used. Sirolimus is a potent immunosuppressant (used to prevent solid organ graft rejection) with a long half-life and the trough level should be closely monitored. It specifically impairs T-cell function, and in the context of VA therapy should be combined with good prophylaxis for pneumocystis infection with either oral trimethoprim/sulfa, dapsone, or pentamidine (via nebulizer mask or IV) using regimens established in the oncology literature.

The optimum sirolimus trough target level is unknown. Good results have been seen at levels below those aimed for in solid organ transplant; however, current practice for KHE treatment in many VA centers recommend a relatively high trough of 10 to $15 \mathrm{ng} / \mathrm{mL}$, although this has yet to be validated in large prospective trials. At these levels, most children do not develop debilitating side effects although mucositis, cytopenias, headaches, and immunocompromise-related infections can occur, which must be monitored for and the dosage adjusted accordingly. Sirolimus also affects lipid metabolism and many patients on this medication will develop hyperlipidemia and hypercholesterolemia. Some of this can be managed with diet, but many patients may need statins or other lipid lowering drugs if they need to stay on the mediation for prolonged periods.

Although propranolol is mostly known for its effects on true hemangiomas, there is also evidence that it can be a helpful adjunct in the treatment of KHE. ${ }^{16,17}$ Though many experts feel that propranolol is helpful in these cases, it is unlikely to work as a single agent. How often this is successful and how much it adds to response is controversial. ${ }^{18,19}$

Tufted angioma (TA) is a lesion that many feel is part of a spectrum of disease with KHE because the appearance on the skin of an affected child (usually under 1 year old) is similar. However, histologically TA stains with the same lymphatic endothelial markers as KHE, but is marked by what are usually described as swirls or "cannon ball-" like formation of spindle cells. Tufted angioma can occasionally present with KMP and the treatments are similar to those used on KHE. As such, the lesion can be excised with intent for cure if it can be fully removed by surgery without creating secondary deformities. Otherwise, medical therapy with vincristine and steroids is commonly used and propranolol is often given adjunctively. There is a literature for TA responding to vincristine, aspirin, and ticlopidine (VAT), but as of yet there are no reports of response with sirolimus. ${ }^{20,21}$ Due to the rarity of $\mathrm{TA}$, it has not been possible to run a randomized controlled treatment trial, and the first such trial for KHE is close to opening in a few U.S. Centers.

\section{Case 1 (KHE)}

A 2-month-old female infant presented with a history of bluish-purple cutaneous discoloration of the left chest. Relevant laboratory investigation included KMP platelets $(24,000 /$ $\mathrm{mm}^{3}$ ), elevated D-dimer ( $>20 \mu \mathrm{g} / \mathrm{dL}$ ), hypofibrinogenemia (143 mg/dL) and anemia (Hgb $8.6 \mathrm{~g} / \mathrm{dL}$ ). - Fig. 1 shows chest $\mathrm{X}$-ray, computed tomography (CT), and magnetic resonance imaging (MRI) findings at diagnosis, which includes an intensely enhancing infiltrative vascular tumor crossing multiple tissue planes involving the left chest wall, neck, and extrapleural space associated with hemothorax. There was extension into the superior mediastinum with displacement of the airway to the right. The diagnosis of KHE was made on surgical biopsy, and the patient was started on vincristine and prednisone. Due to poor initial response of KMP and failure of the mass to shrink, propranolol and then sirolimus were added to the medical regimen (at 2 weeks and 2.5 months from the beginning of the treatment, respectively). The KMP resolved and the mass began to regress. The platelet count returned to normal at 7 months and has remained normal at 12-month follow-up. All drugs except sirolimus were gradually weaned off. - Fig. 2 shows follow-up MRI obtained at 4, 10 , and 16 months postcommencement of treatment showed progressive reduction in the volume of the vascular tumor and progressive replacement with fat. There was progressive reduction in $\mathrm{T} 2$ hyperintensity and improved demarcation of soft tissue planes. There was complete resolution of the hemothorax and mediastinal shift with $<1 \%$ residual tumor mostly within the neck.

\section{Vascular Malformations}

Within the ISSVA classification, there are multiple rare diagnoses in the vascular malformation category. Many of these disease entities are cured or managed primarily with surgical techniques. Others may require conservative medical approaches, including compression garments and/or chronic anticoagulation in some cases of complicated venous malformations. ${ }^{21}$ Recently, there have been efforts to use some of the same medications (principally vincristine, glucocorticoids, and sirolimus) used on proliferative vascular tumors on entities that have been traditionally described as malformations. The areas where this has been most successful to date are blue rubber bleb nevus syndrome and some lymphatic malformations.

\section{Blue Rubber Bleb Nevus Syndrome}

Blue rubber bleb nevus syndrome (BRBNS) is a rare vascular anomaly with $\sim 200$ documented cases in the literature; however, the true incidence is not known. ${ }^{22}$ The common skin lesions are "blebs," which can be characterized as circumscribed, multifocal lesions that can vary greatly in size (2 mm to $10 \mathrm{~cm}$ ), which are a dark blue in color, soft, 


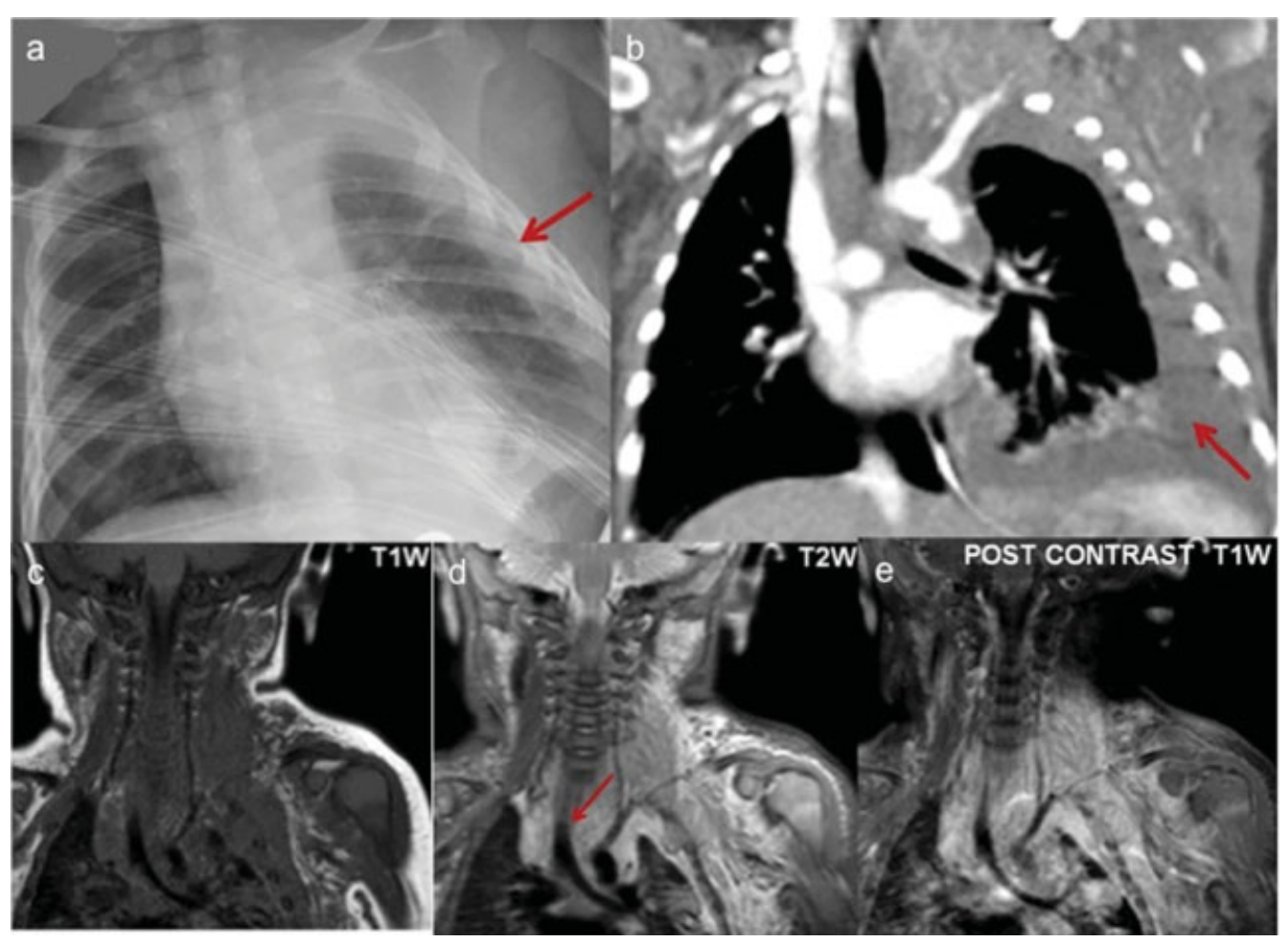

Fig. 1 Management of infant with kaposiform hemangioendothelioma. (A,B) Chest x-ray and coronal reconstructed computed tomography scan demonstrate soft tissue mass in left neck, chest wall, and superior mediastinum with hemothorax (arrows). (C-E) Coronal T1-weighted (T1W), $\mathrm{T} 2 \mathrm{~W}$, and postcontrast T1W magnetic resonance images (MRIs), respectively, demonstrate an intensely enhancing infiltrative vascular tumor crossing multiple tissue planes involving the left chest wall, neck, and extrapleural space. The tumor extends into the superior mediastinum and displaces the airway to the right (arrow).

rubbery, and compressible on palpation. Three types of lesions have been described in BRBNS: (1) blue, rubbery, blood-filled sacs with a smooth or wrinkled surface that are easily compressible and promptly refill when pressure is removed; (2) large, disfiguring, cavernous lesions that may compress vital structures; and (3) blue, irregular macules. ${ }^{23}$ The lesions are most commonly found cutaneously and in the gastrointestinal tract (GI); however, they can also be found in any organ and soft tissues, including the central nervous system. Blue rubber bleb nevus syndrome affects males and females equally and usually presents in infancy or earlier childhood; however, there have been documented cases in which it has presented in adulthood. The exact etiology is unknown. Although most cases are spontaneous, there are a few reported cases associated with an autosomal dominant inheritance pattern with a locus found on chromosome 9p. ${ }^{24}$

There are several symptoms that may manifest secondary to the blebs. The cutaneous blebs are usually painless, whereas GI lesions can spontaneously rupture and hemorrhage. However, the bleeding is more often indolent in nature, causing iron deficiency and anemia from slow chronic blood loss. Other GI symptoms may include vague abdominal pain,

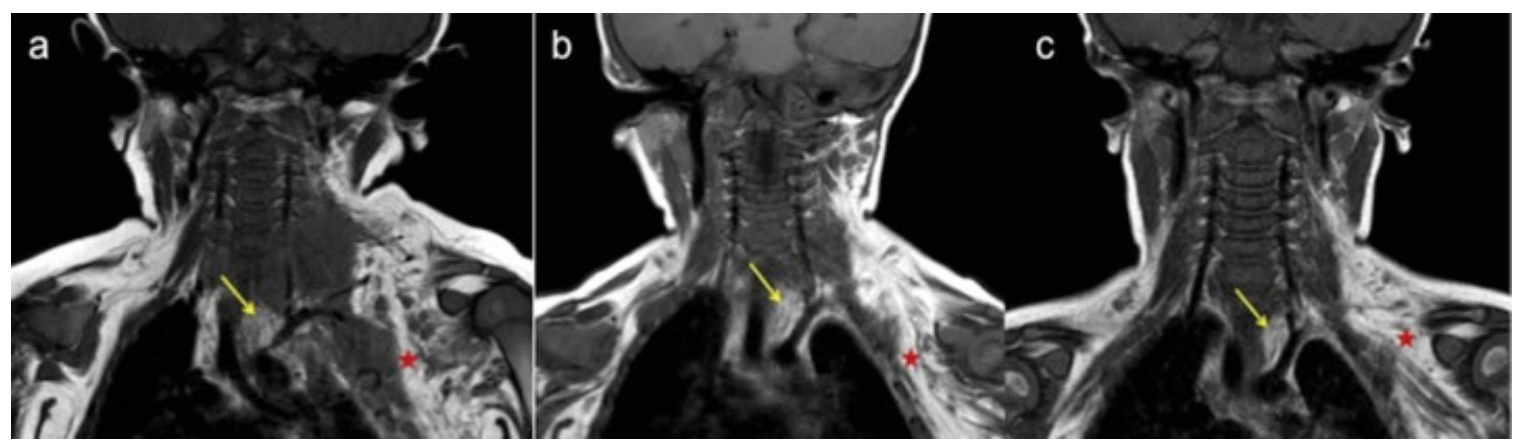

Fig. 2 Magnetic resonance imaging monitoring following treatment progression. (A-C) Coronal T1-weighted magnetic resonance images obtained at 4,10, and 16 months postcommencement of treatment demonstrate progressive reduction in the volume of vascular tumor and replacement with hypertrophic fat. There was complete resolution of hemothorax and mediastinal shift with $<2 \%$ residual tumor. 
chronic anemia or consumptive coagulopathy, intussusception, volvulus, intestinal infarction, melena or hematochezia, and in the worst case, hypovolemic shock caused by overt GI bleeding from ruptured GI lesions. ${ }^{23}$ Orthopedic manifestations of BRBNS are rare, but include skeletal bowing, pathologic fractures, bony overgrowth, articular derangements or bone deformities, and spinal compression and vertebral collapse, all of which can affect range of motion and impair ambulation. ${ }^{25}$ There is also a possibility, although extremely rare, of thromboembolic events.

There is no cure for BRBNS; there have been several treatment modalities utilized including pharmacological antiangiogenic agents such as corticosteroids, interferon- $\alpha$, thalidomide, and more recently, sirolimus. ${ }^{26}$ Although debated in the literature for the potential for recurrence, both wedge and complete excision of GI lesions have been successfully implemented in a few cases. ${ }^{23}$ At the present time, these types of procedures should only be done within or in close consultation with a vascular anomalies center. There are also supportive care treatments often needed for these patients like PRBC transfusions, antifibrinolytic agents, and anticoagulation medications. Although the treatment options are limited and none are currently known to be curative, significant progress has made BRBNS a manageable chronic condition.

\section{Lymphatic Malformations Treated with Sirolimus}

Macrocystic lymphatic malformations (LMs) are usually treated with surgical excision or IR sclerotherapy. ${ }^{1,2,21}$ Unfortunately, this will not work for all macrocystic lesions and does not work well for microcystic lesions. The following case shows an ongoing attempt at our own center to manage an LM that was failing other therapies with sirolimus.

\section{Case 2 (LM)}

A newborn infant noted to have a large mixed macro- and microcystic LM of the head and neck involving most of the left neck, anterior mediastinum, floor of mouth, and the tongue (-Fig. 3A). Since birth, the child has not been able to fully retract her tongue into her mouth. The lesion was originally noted on prenatal ultrasound. The patient was delivered by an elective C-section with an ex utero intrapartum (EXIT) procedure, and underwent elective intubation and stabilization. On the second day of life, the patient underwent an extensive resection of part of the neck mass and had a tracheostomy placed. This was followed by a series of eight sclerotherapy procedures over 12 months by IR (-Figs. 3B,C). Over time, the macrocystic portions of the lesion became replaced by microcysts and new lymphatic macro- and microcysts continued to develop in the treated areas. The tongue was particularly problematic, as a large portion the tongue remained external to the mouth desiccated, cracked, and bleeding. At 17 months of age, the patient was referred to the hematology/oncology specialty for a trial of sirolimus (-Figs. 4 A,B). This patient rarely met the sirolimus target trough level range of 10 to 15 $\mathrm{ng} / \mathrm{mL}$ and more typically had a levels of $<10 \mathrm{ng} / \mathrm{mL}$ and often $<2 \mathrm{ng} / \mathrm{mL}$. Despite difficulties with maintaining the desired sirolimus levels, there was a significant reduction in

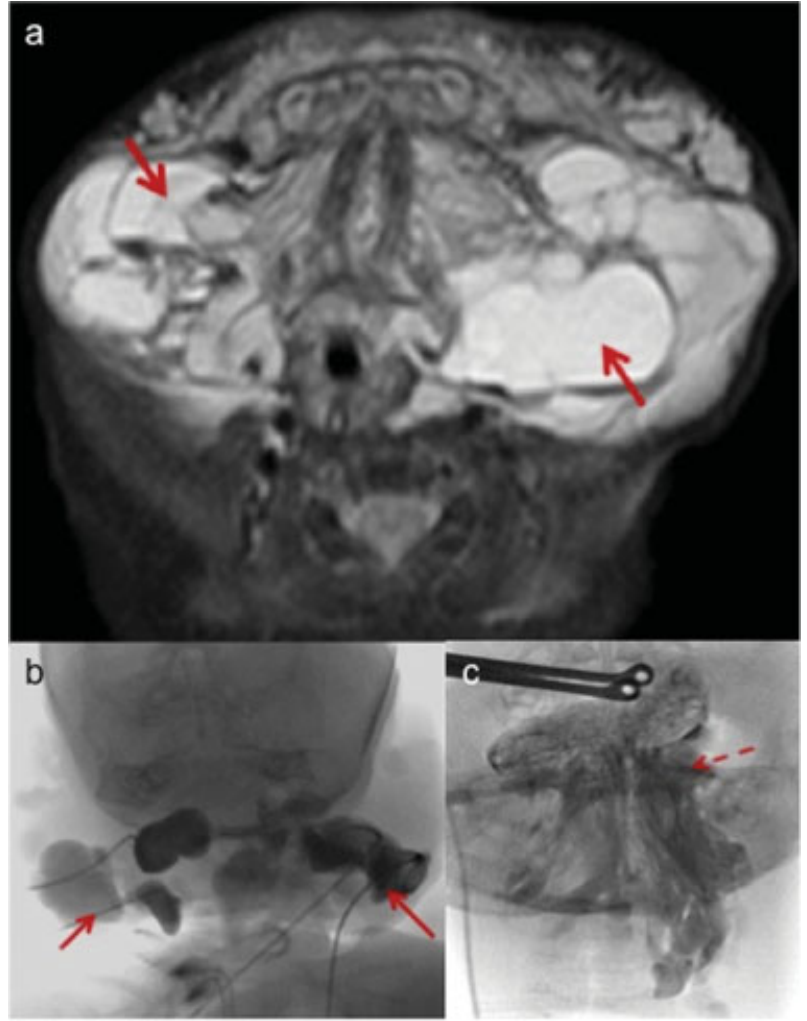

Fig. 3 Management of mixed macro-microcystic lymphatic malformation using sirolimus. (A) Axial T2-weighted magnetic resonance image at birth shows infiltrative transspatial mixed macro-microcystic lymphatic malformations. (B,C) Fluoroscopic image during sclerotherapy shows contrast-opacified doxycycline within lymphatic cysts in the neck (solid arrows) and tongue base (dashed arrow).

the size of the malformation (-Figs. 4 C,D). The patient has recently gained the ability to pull her tongue completely into her mouth. Swallowing and speech have also improved, although the patient still requires a tracheostomy and receives $\sim 50 \%$ of her nutrition by gastrostomy tube. Current plans include renewed attempts to maintain a consistent sirolimus trough level of 10 to $15 \mathrm{ng} / \mathrm{mL}$ for several months. If and when reduction of the malformation appears to plateau, a surgical reduction of the tongue itself along with further sclerotherapy of the floor of the mouth region will be performed.

There has been some success using sirolimus and other immunotherapies (i.e., interferon), as well as more traditional chemotherapy agents with other vascular malformation syndromes, including phosphatase and tensin homolog (PTEN) mutation syndrome, generalized lymphatic anomaly (GLA), Gorham-Stout disease (GSD), and the newly described kaposiform lymphagiomatosis. ${ }^{27-31}$ Attempts to find adjunctive therapies for vascular malformations are crucial because traditional methods, including surgical excision/debulking, sclerotherapy, laser, and coblation, often gain the patient some initial control of the VM, but do not cure the disease. Further treatment is often required for expected recurrence during the child's growth period. Some VMs remain a challenge for initial control due to the vast extent of tissue involvement, and active angiogenesis often replaces treated 


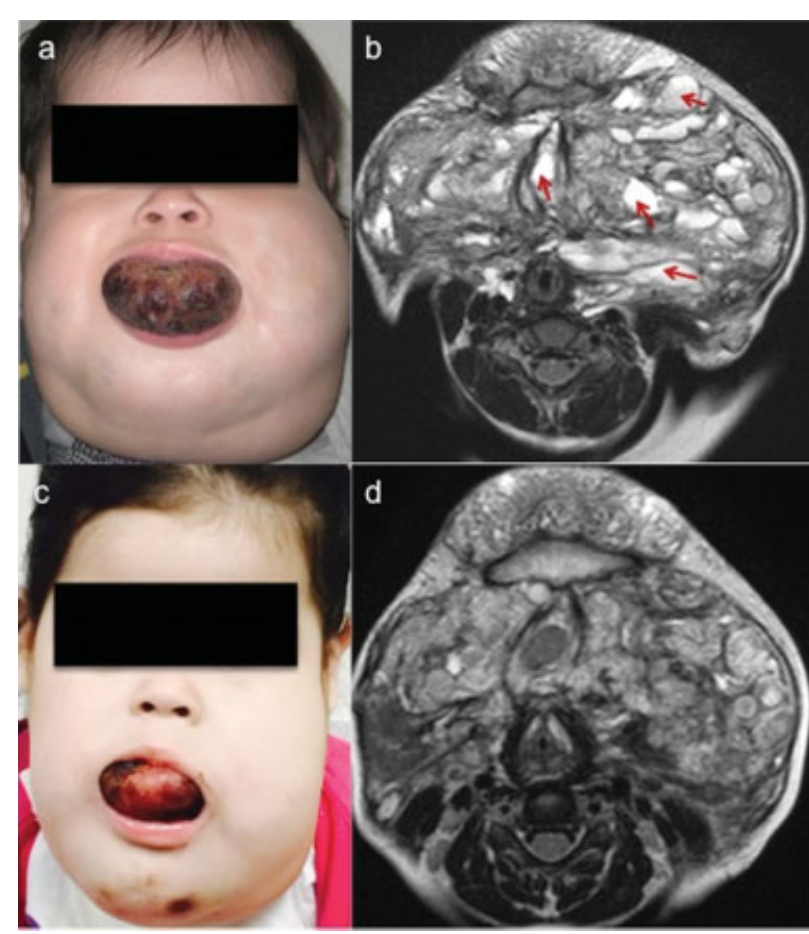

Fig. 4 (A) Clinical photograph (age: 17 months) at conclusion of sclerotherapy and prior to commencement of sirolimus shows diffuse neck swelling and protrusion of tongue from oral cavity. (B) Axial T2weighted magnetic resonance image (T2W MRI) at the same time shows multiple hyperintense lymphatic microcysts (arrows) in bilateral submandibular, sublingual, parapharyngeal, and preverterbral spaces. (C) Clinical photograph (age: 29 months) at 1 year postsirolimus treatment shows reduction in neck swelling and retraction of tongue within the oral cavity. (D) Axial T2W MRI at the same time points shows reduction in volume of lymphatic malformations and darkening of cystic spaces suggestive of sclerosis.

areas at a rapid rate (weeks rather than years). These VMs should be considered for angiogenic inhibitor treatment either independently or as a supplement to ongoing treatments. Due to the rarity of most of these diagnoses and the need for multi- and interdisciplinary care, practitioners are encouraged to avail themselves of the multiple available VA center consultation mechanisms. A center referral gives both the practitioner and the patients access to the most up-todate information, as well as access to treatment protocols (many of which can be implemented by the referring physician) and disease registries that will advance this field.

\section{References}

1 Adams DM, Wentzel MS. The role of the hematologist/oncologist in the care of patients with vascular anomalies. Pediatr Clin North Am 2008;55(2):339-355, viii

2 Guevara CJ, Alomari AI. Interdisciplinary approach to treatment of vascular anomalies. Tech Vasc Interv Radiol 2013;16(1):55-58

3 Enjolras O, Wassef M, Chapot R. Color Atlas of Vascular Tumors and Vascular Malformations. New York, NY: Cambridge University Press; 2007:1-11

4 Kollipara R, Dinneen L, Rentas KE, et al. Current classification and terminology of pediatric vascular anomalies. AJR Am J Roentgenol 2013;201(5):1124-1135
5 Tekes A, Koshy J, Kalayci TO, et al. SE Mitchell Vascular anomalies flow chart (SEMVAFC): A visual pathway combining clinical and imaging findings for classification of soft-tissue vascular anomalies. Clin Radiol 2014; 69(5):443-457

6 Hassanein AH, Mulliken JB, Fishman SJ, Greene AK. Evaluation of terminology for vascular anomalies in current literature. Plast Reconstr Surg 2011;127(1):347-351

7 Soltani AM, Reinisch JF. Algorithmic approach to the management of hemangiomas. J Craniofac Surg 2011;22:585-588

8 Yang JY, Chan AK. Pediatric thrombophilia. Pediatr Clin North Am 2013;60(6):1443-1462

9 Adams DM. Special considerations in vascular anomalies: hematologic management. Clin Plast Surg 2011;38(1):153-160

10 Fernández Y, Bernabeu-Wittel M, García-Morillo JS. Kaposiform hemangioendothelioma. Eur J Intern Med 2009;20(2):106-113

11 Croteau SE, Liang MG, Kozakewich HP, et al. Kaposiform hemangioendothelioma: atypical features and risks of Kasabach-Merritt phenomenon in 107 referrals. J Pediatr 2013;162(1):142-147

12 Vetter-Kauczok CS, Ströbel P, Bröcker EB, Becker JC. Kaposiform hemangioendothelioma with distant lymphangiomatosis without an association to Kasabach-Merritt-Syndrome in a female adult!. Vasc Health Risk Manag 2008;4(1):263-266

13 Blatt J, Stavas J, Moats-Staats B, Woosley J, Morrell DS. Treatment of childhood kaposiform hemangioendothelioma with sirolimus. Pediatr Blood Cancer 2010;55(7):1396-1398

14 Hammill AM, Wentzel M, Gupta A, et al. Sirolimus for the treatment of complicated vascular anomalies in children. Pediatr Blood Cancer 2011;57(6):1018-1024

15 Vignot S, Faivre S, Aguirre D, Raymond E. mTOR-targeted therapy of cancer with rapamycin derivatives. Ann Oncol 2005;16(4): 525-537

16 Starkey E, Shahidullah H. Propranolol for infantile haemangiomas: a review. Arch Dis Child 2011;96(9):890-893

17 Tlougan BE, Lee MT, Drolet BA, Frieden IJ, Adams DM, Garzon MC. Medical management of tumors associated with Kasabach-Merritt phenomenon: an expert survey. J Pediatr Hematol Oncol 2013; 35(8):618-622

18 Chiu YE, Drolet BA, Blei F, et al. Variable response to propranolol treatment of kaposiform hemangioendothelioma, tufted angioma, and Kasabach-Merritt phenomenon. Pediatr Blood Cancer 2012; 59(5):934-938

19 Wang Z, Li K, Dong K, Xio XDOI, Zheng S. Letter to the Editor concerning ref 18 above. Pediatr Blood Cancer 2014

20 Fernandez-Pineda I, Lopez-Gutierrez JC, Chocarro G, BernabeuWittel J, Ramirez-Villar GL. Long-term outcome of vincristineaspirin-ticlopidine (VAT) therapy for vascular tumors associated with Kasabach-Merritt phenomenon. Pediatr Blood Cancer 2013; 60(9):1478-1481

21 Blei F. Medical management of vascular anomalies. Facial Plast Surg 2012;28(6):575-583

22 Ganesh R, Reddy M, Janakiraman L, Sathiyasekaran M. Blue rubber bleb nevus syndrome. Indian J Pediatr 2014;81(3):317-318

23 Choi KK, Kim JY, Kim MJ, et al. Radical resection of intestinal blue rubber bleb nevus syndrome. J Korean Surg Soc 2012;83(5): 316-320

24 Krishnappa A, Padmini J. Blue rubber bleb nevus syndrome. Indian J Pathol Microbiol 2010;53(1):168-170

25 McCarthy JC, Goldberg MJ, Zimbler S. Orthopaedic dysfunction in the blue rubber-bleb nevus syndrome. J Bone Joint Surg Am 1982; 64(2):280-283

26 Yuksekkaya H, Ozbek O, Keser M, Toy H. Blue rubber bleb nevus syndrome: successful treatment with sirolimus. Pediatrics 2012; 129(4):e1080-e1084

27 Iacobas I, Burrows PE, Adams DM, Sutton VR, Hollier LH, Chintagumpala MM. Oral rapamycin in the treatment of patients with hamartoma syndromes and PTEN mutation. Pediatr Blood Cancer 2011;57(2):321-323 
86 Medical Therapy for Pediatric Vascular Anomalies Margolin et al.

28 Iacobas I, Burrows PE. Role of PTEN in vascular organization and anomalies. In: Xu K, ed. PTEN: Structure, Mechanism of Action, Role in Cell Signaling, and Regulation; New York, NY: Nova Science Publishers; 2013:211-233

29 Venkatramani R, Ma NS, Pitukcheewanont P, Malogolowkin MH, Mascarenhas L. Gorham's disease and diffuse lymphangiomatosis in children and adolescents. Pediatr Blood Cancer 2011;56(4): 667-670

30 Croteau SE, Kozakewich HP, Perez-Atayde AR, et al. Kaposiform lymphangiomatosis: a distinct aggressive lymphatic anomaly. J Pediatr 2014;164(2):383-388

31 Safi F, Gupta A, Adams D, Anandan V, McCormack FX, Assaly R. Kaposiform lymphangiomatosis, a newly characterized vascular anomaly presenting with hemoptysis in an adult woman. Ann Am Thorac Soc 2014;11(1):92-95

32 McClain KL, Kozinetz CA. A phase II trial using thalidomide for Langerhans cell histiocytosis. Pediatr Blood Cancer 2007;48(1): 44-49

33 Botero JP, Burs D, Thompson CA, Pruthi RK. Successful treatment with thalidomide of a patient with congenital Factor $\mathrm{V}$ deficiency and Factor $\mathrm{V}$ inhibitor with recurrent gastrointestinal bleeding from small bowel arteriovenous malformations. Haemophilia 2013; 9(1):e59-e61PubMed

34 Blinc A, Golli T, Vodnik AC, Zver S. Concurrent thalidomide and radiation therapy for extensive arterio-venous malformations. Thromb Haemost 2008;99(1):235-237 